\title{
The Power of Song
}

\author{
Dieuwke van der Poel
}

In the metropolitan sixteenth-century city of Antwerp, printers began to realize that song might be a profitable genre for the relatively new technology of the printed book. ${ }^{1}$ In a period of about 25 years, from 1539 to 1565 , a number of major songbooks were printed. Some have interesting prologues and prefaces. The first part of this paper will present and analyze four of these paratexts to distil their intriguing views on singing, and about song as a medium. The second part will discuss some reasons why song is considered as an influential medium, according to medieval as well as modern views.

The Devout and Beneficial book (Devoot ende profitelyck Boecxken), printed in 1539 by printer Simon Cock, contains more than 25 o religious songs and as such is by far the largest songbook to appear on the European continent by that date. ${ }^{2}$ The book opens with an extensive prologue in which its author, probably Simon Cock himself, explains why he assembled this collection. ${ }^{3}$ First he discusses the fact that especially young people are easily drawn to sin; among the most dangerous threats for them are the many improper and indecent worldly songs and refereynen 4 ('veel ontamelike oneersame weerlike liedekens ende refereynen') which are unfortunately widespread among young people. Such

1 With special thanks to Hermina Joldersma for keeping a watchful eye on my English.

2 Scheurleer (1889). This important songbook has more than 200 devout songs, arranged according to their melodies: all songs with the same melody are assembled and the first song of such a group has musical notation and a melody reference. Therefore the book could be used by people who were able to read musical notation as well as by those who could not. Because of the abundant number of songs with melodies, the book has been significant for the reconstruction of melodies of songs from other sources, such as the Antwerp Songbook. From the point of view of literary history, the book is interesting because it is the first printed collection that contains the work of rhetoricians, see: Van der Poel, Geirnaert, Joldersma, Oosterman and Grijp (2004) part 2, 9-47. The songs are discussed in: Knuttel (1906). For the international context see: Siertsema (1993).

3 For the attribution to Simon Cock, see Vellekoop (1997) 109.

4 The word refereyn may refer to two different types of texts: the refrain, the repetition of the same line(s) at the end of each stanza, or a poem consisting of stanzas of eight lines or longer, with a so-called stokregel at the end of each stanza, providing the theme or the pointe of the poem.

(C) DIEUWKE VAN DER POEL, 2020 | DOI:10.1163/9789004291911_004

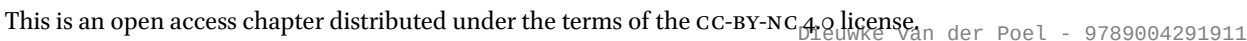


songs and refereynen promote an inclination to evil and will inflame the whole body with the fire of carnal desire, corrupting the blood like the plague until death follows, unless an early remedy is sought. Parents and shepherds of souls should forbid this! Just as God, on the day of judgement, will demand a justification for each idle word, so will he ask the sinner about reading, singing or composing indecent and improper songs and refereynen.

Next, the author mentions his sources: he has searched with great diligence among religious and secular people, in several monasteries and cities and in six countries, for all religious songs and carols that he could possibly find, and he even had others write as many songs as possible within the available time frame ('ende ooc doen dichten so vele alst op dese tijt mogelijck is gheweest'). He then assembled the songs into a book so that everyone might have the opportunity to enlighten the spirit and refrain from the idleness which is so disgusting to God. After all, songs can please God: for this the author provides biblical references such as the harp-playing and psalms of David, and the songs of Miriam, the sister of Aaron. ${ }^{5}$ Similarly, he says, the Holy Church teaches that the Lord should be praised every day with sweet song: so why should not lay and religious people and beguines thank and praise the Lord with a devotional song and awaken the sleeping spirit, burdened as it is with the mortal body? He underpins this with quotes from Paul and the apostles Mark and Matthew.

Therefore, all devoted hearts should alternate in thanking the Lord in prayer, in praising Him with a sweet song, in inciting the heavy body with a song about death or the Last Judgment, or in seeking mercy and comfort through Jesus, with the help of Mary. Everyone will find such songs in abundance in the book.

The author ends his prologue by asking the readers to pray for him and for everyone involved in composing the book.

Indirectly, this prologue gives us a fascinating glimpse of the contemporary attitude towards song, and a negative attitude it is. Essentially, song is considered to be a threat to the salvation of the soul: there are many indecent and improper songs, particularly dangerous for youngsters, who furthermore love to sing. By defending the religious use of song so passionately, the author only emphasizes the bad reputation of worldly song. Song is so dangerous because it attacks the body, corrupting the blood and causing dangerous diseases, like the plague. ${ }^{6}$

5 This is a reference to Miriam in Exodus 15:20-21.

6 This is also of interest because the author portrays himself as an early example of a field collector, gathering songs and asking people to write songs for his book. 
In the next year, 1540, Symon Cock rolled out another interesting songbook, the so-called Souterliedekens: the first collection of the psalms in the vernacular, set to the melodies of worldly songs. ${ }^{7}$ This was a genuine bestseller, with no less than eight reprints in one year (all produced by Cock). ${ }^{8}$

The author, probably a nobleman from Utrecht, Willem van Zuylen van Nyevelt, also composed the prologue. Making reference to the first of the Ten Commandments, he stresses the importance for every Christian of hallowing God's name. But God's venerable name is violated so frequently in frivolous and vain songs that he has felt the need to gather these psalms with effort and hard work in order to prevent such evil, and to provide youth with an alternative to the many foolish and lewd songs. Now because the prophet David provided such rich material in the Psalms, in the Souterliedekens each text is set to the music of a worldly song and accompanied by notes of music in order that those who don't understand music will be able to learn the melody from someone who does. The words follow the original as closely as possible. Sometimes it turned out to be impossible to follow the text exactly because of the (musical) form, but nevertheless, the essence of the text was not altered.

The author expresses the hope that his reader will notice that these songs were made for the purpose of hallowing God's name and that youngsters, who are naturally inclined to song, will take pleasure in religious song pleasing to God, as recommended by the apostle Paul (Colossians 3:16). He stresses the importance of listening to the essence of the words, more than to the sound of the voice, once again referring to Paul (ICorinthians 14:15). The singer should sing these songs with true devotion and with a heart raised to God, and not in the way in which frivolous popular songs are sung. When sung devoutly they will profit listeners as well as singers. Referring to a church father, Athanasius of Alexandria, the author states that godly songs might be used to provide improvement in our lives, consolation for our suffering and solace for our grief. Accordingly he advises: 'when you are good-humoured and you want to surren-

7 Van Biezen and Veldhuyzen (1984). In this book all 15 o psalms and some hymns are translated into the vernacular and set to music by the poet. He chose for each psalm a different melody, providing the melodies in mensural notation (these give an indication of the rhythm) and giving name references to the melodies. As many of these references refer to songs of the Antwerp Songbook, the Souterliedekens have been extremely important for the reconstruction of melodies of that collection, see Van der Poel, Geirnaert, Joldersma, Oosterman, and Grijp (2004). For the connection between the Souterliedekens and the Reformation, see: Grijp (2001) and De Gier (1987).

8 For details, see the Dutch Song Database: www.liederenbank.nl, and Scheurleer (1977). The standard work is Lenselink (1983), with references to earlier work on the history of Dutch psalms in the 16th century. 
der to joy, then you should enjoy yourself by praising God in a way that pleases God, rather than exciting your flesh with unseemly songs with which you please the devil' ('als ghi goets moets zijt, ende tot vruechden u wilt gheven, so wilt liever uwen gheest vermaken met Gods lof, daer ghi God mede behaget, dan dat ghi u vleesch met onduechdelicke sanghen sout verwecken, daer ghi den duvel mede behaecht').

So, he says, wherever you are - whether alone, with your family, with Godfearing companions, on a journey, in the fields, or at the table-instead of gossip, rash and vain words, foolish and boastful dispute, or having a drink together, as is usually done at banquets nowadays, rather sing some of these songs in order to praise the name of our Lord, to stay out of the devil's trap and to spend your time like a Christian. The devil will not be able to catch youhe shall not have any reason to do so, because of your worthwhile occupation with song.

A comparison with the Devout and Beneficial Book shows similarities as well as differences. Most obvious is the association between song and having fun, especially with communal fun: singing is clearly something done in a group. At the same time, song is associated with drinking and bad language as well, so singing can be dangerous. Singing lewd songs excites the flesh (although there is less stress on this physiological effect of songs here) and turns the singer into a prey for the devil. Again, youngsters are mentioned as the group most typically involved in singing. And here again, a Christian use of song is defended: since the young are singing anyway, let them sing something good. The concern for the correctness of the texts in the Souterliedekens can be explained by their biblical origins; such textual correctness is not always insisted on for religious songs.

Eleven years later, yet another interesting songbook was printed in Antwerp: The first music book (Het Ierste Musyck Boexken) by the Flemish publisher, composer and musician Tielman Susato. ${ }^{9}$ He introduces himself as an experienced printer of masses, motets and French chansons, and with good reason, for in $155^{1}$ he had published several songbooks with French repertoire. But this time, he says, he intends to publish the heavenly art of music in his Dutch mother tongue: he has assembled the choicest and most artful songs into three books, leaving out those songs that might encourage mischief through indecent words. He goes on to ask all talented writers ('constighe geesten') to use Dutch whenever they write songs and to let him have them: he will put them into print

9 Riemsdijk (1888) 61-110. See also: Bonda (2001), Polk (2005) and Forney (1982-1984). 
and distribute them widely, as long as the poets shun indecent and improper words that might disgrace the heavenly art and defile young spirits who should instead be incited to virtue. For Music is a heavenly gift, not given to mankind to abuse, but so that we may praise the Lord gratefully, shrink from idleness, gain time, chase away melancholy, enlighten depressed spirits and gladden restless hearts. According to Susato the mother tongue is as appropriate to do this as any other language. ${ }^{10}$

This preface is well known for its remarkable defence of the use of Dutch, but it also contains interesting views on song. Several issues are familiar: song particularly affects young people, and it is frequently improper. Nevertheless, Susato stresses song's religious dimension far less, though this should not surprise us when we take into account that his is a secular songbook. Still, music is called useful when it praises the Lord, cheers our hearts, and chases away melancholy; even in a worldly songbook, song is defended as a heavenly gift that should not be abused. Furthermore, Susato states that song has a profound influence on humans: it can uplift the heart and dispel melancholy. Finally, it is interesting to see that despite the condemnation of songs with improper and indecent words, nearly half of the songs in the Musyck Boexkens can be labelled as songs of folly ('zotte liedekens'), songs portraying lovers, prostitutes, drinkers, gamblers, big spenders and beggars. ${ }^{11}$

The last preface to be discussed, Jan Fruytiers' introduction to Ecclesiasticus, printed by Willem Silvius in Antwerp in 1565 , is the most extensive. ${ }^{12}$ As the title indicates, this songbook paraphrases the text of Ecclesiastes. In his extensive prologue, Fruytiers develops a metaphor: the Book of Sirach is like an orchard, full of trees with blessed biblical fruit, tasty for true Christians, but a cause of toothache and belly pain for those not dedicated to God, bitter and hard to swallow for sinners; but for wise, God-fearing, virtuous people the fruit will be nutritious and sweet as honey.

In the songbook the text of Jesus Sirach is set to music for learning and edification. Some may despise these songs simply because they disapprove of songs of praise or are offended by rhymes, but Fruytiers has ammunition against such an appraisal: referring to Moses and Miriam, Debora and Barak,

\footnotetext{
10 For an English translation of the preface, see McTaggart (1997) 316.

11 McTaggart (1997).

12 Scheurleer (1898). As it provides musical notation for 116 melodies, this is again a very important source for the reconstruction of melodies of secular songs, in particular from the Antwerp Songbook, see Van der Poel, Geirnaert, Joldersma, Oosterman, and Grijp (2004).
} 
he proves that in biblical times it was quite common to praise the Lord by singing. Many prophets, too, stressed the importance of hymns, and many figures from the Old Testament praised the Lord by singing or maintained the importance of such songs (Fruytiers provides exact biblical references). And this is not limited to the Old Testament. At Jesus' birth all the angels sang; again, Fruytiers lists quotations from the Gospels and other books of the Bible showing that songs of praise are in accordance with Scripture and pleasing to God.

The next paragraph describes how these songs should be sung. It notes the importance of Paul's words about the correct manner for singing: we should sing in our hearts and soul and with our reason-and not listen too much to the sound of the voices but rather to the inner meaning of the words. Therefore, singing should be done sweetly, softly and with moderation. If we do, song will be powerful and enflame the heart; such songs will pierce the clouds and praise the Lord. One's soul will be lifted towards Him and one's neighbour will be improved. According to St Augustine, it is a sin to be moved rather by the sweetness of the voices than by the meaning of the words.

In conclusion Fruytiers states that singing as well as reading the text of these songs will lead to virtue, and that he has tried his best to render the text of Ecclesiastes as faithfully as possible. He may publish something else in the near future.

I have provided only a short summary of this extensive preface, as I have omitted most of the extensive biblical references intended to underpin the religious use of song.

This preface obviously differs from the ones discussed so far: it contains no complaints about indecent songs, no reference to young people as singers and susceptible listeners. But there are interesting similarities as well. Singing itself is considered intrinsically dangerous because the sweet sound of the human voice might distract singers and listeners from the message, and therefore song quite easily leads to sin. The Souterliedekens contained a similar warning to keep the mind focussed on the meaning of the song, instead of letting oneself be carried away by the sensual qualities of the human voice, but this was only mentioned in passing. In Ecclesiasticus, Fruytiers is far more explicit on this subject.

Ecclesiasticus is provided with a second paratext in the form of an Ode to the songs of the book, written by painter and poet Lucas d'Heere. Here again we encounter the theme of the danger of sensual songs. The Ode is addressed to the 'earthly human being' who uses his voice for lecherous sinful matters instead of honouring God, and who draws his neighbour to evil by carnal songs, instead of inciting him to good by useful lessons. D'Heere urges 
us to flee from this villainy and sing these Godly songs from a cheerful heart, and to break the habit of singing wicked songs, which are full of poison. He claims that these songs will pull the heart towards the heavenly choirs, where our home should be forever. In this way the Ode centres on the opposition between the dangers of wicked secular song and the beneficial effects of religious song.

In sum, these four prefaces of songbooks printed in Antwerp between 1539 and 1565 agree that song had a bad reputation. There seem to be two distinct reasons for this: on the one hand the subject matter of secular songs is condemned, on the other the medium of song is considered dangerous because it has a profound physical influence and emotional impact. Songs could enflame the body and excite the flesh, and it is easy to get carried away by the beauty of the melody (although song can have a beneficial effect as well, by dispelling melancholy and lightening heavy spirits, according to Susato).

The question arises as to whether these prefaces are reliable witnesses of a prevalent negative attitude towards song during the sixteenth century: one could argue that these writers and printers had a hidden agenda, discrediting other songbooks in order to sell as many copies as possible of their own. There may be some truth in this, but other sources also express the view that improper songs were numerous, indicating that song did have a bad reputation, and that singing was regarded as exerting a dangerous influence.

For example, in 1580 the carillonneur of Antwerp was forbidden to play indecent or forbidden songs on the tower carillon of the Cathedral of Our Lady, and the 1591 Synod of Dockum forbade the singing of lewd songs while dancing. Records frequently mention penalties for singing indecent or mocking songs ('schimpliederen') and songs criticising Catholicism or political figures. $^{13}$

It is likely that objectionable songs had a lower survival rate than other songs, because they were not often written down or printed. Sometimes only a small trace remains, such as a melody reference. For example, the melody reference for psalm 136 in the Souterliedekens is clearly sexual: 'On the melody of a dance song. Lijnken was about to bake, my lord was going to knead' ('Na die wise van een danslieken. Lijnken sou backen, mijn heer sou kneen'). In other sources the reference is shortened to 'Lijnken's oven has been floured' ('Lijnkens oven

13 Bax (1944) esp. 254-255. For mocking songs, see Pleij (2007) 255-258, and Maes (1947) 249-25o and 68o (with special thanks to Martine Veldhuizen for drawing my attention to this book). 
is bestoven'). ${ }^{14}$ Though it is easy to guess what the content of the song was (the story of Lijnken and one or more lovers), the exact lyrics are unknown because they have not been transmitted.

A relatively large number of indecent songs can be found in the Antwerp Songbook, the major collection of late medieval Dutch song with no less than 221 songs. The only surviving exemplar was printed in Antwerp by Jan Roulans in 1544; it is probable that this is the third, extended edition, which followed the first and second in a relatively short space of time. ${ }^{15}$ It is interesting to see how the songs added in the reprints differ from those in the original edition. For example, more songs tell a farcical story, like song 188 , which is about a woman who cheats on her husband and each of her two lovers. One evening, she wants to receive both her lovers, but she runs out of time and has to hide the first one in the attic when the second one arrives, and the second in a chest when her husband returns home. His suspicions are aroused; the song ends with a comical climax and a quasi-serious moral. Among the lewd songs in this extended reprint are five erotic trade songs, all based on the same compositional principle: the technical terms of some craft are used with a double meaning, as in a song about a maiden who asks the locksmith to file her small lock (song 191). ${ }^{16}$ Most of these songs survive only in the Antwerp Songbook, and their melodies are not extant. These songs seem to be the mayflies of sixteenth-century song, known to us only because printer Jan Roulans gathered as many songs as he could for launching another reprint of his bestselling songbook as soon as possible.

Most often it is impossible to tell which songs were considered offensive, but sometimes an author reveals a bit more. For example, Henricus Costerius, priest of the Cathedral of Our Lady in Antwerp, quotes a song he wanted to replace by a more harmless one. This macaronic song, in Dutch and Latin, goes like this:

Joseph was een Timmerman

Hy dronck so geeren cervisiam

Hy en hadde geen pecuniam, hy vercocht sijnen tunicam.

\footnotetext{
14 There is a reference to a French song as well: 'Le bergier et la bergiere, sont a lumbre dung buysson', probably a pastourelle, see: http://www.liederenbank.nl.

15 Van der Poel, Geirnaert, Joldersma, Oosterman, and Grijp (2004) part 2, 25-31. The extant copy has the songs in three alphabetical series, indicating that with each new print a new series of songs has been added.

16 Van der Poel (2005).
} 
Joseph was a carpenter / He loved to drink cervisiam (beer) / He didn't have any pecuniam (money) / He sold his tunicam (trousers).

Costerius argues that it is wrong to make fun of Joseph's trousers. Interestingly, the trousers of Joseph are a recurring theme in visual art, but not in any songs we know. ${ }^{17}$ The content of the song reminds us of the complaint in the prologue of the Souterliedekens: a frivolous song defaming God's name, or in this case a biblical figure.

This example brings us to the domain of religion, where song became a very influential medium. In Antwerp and Flanders, song was intensively used to spread the new ideas of the reformation. ${ }^{18}$ The catholic chronicler Marcus van Vaernewyck gives an impressive description of large groups of people (he mentions 200 or 300 !) roaming the streets of Ghent in 1566, singing with great enthusiasm psalms they had learned during field preaching. ${ }^{19}$ Singing heterodox songs was banned from $15^{21}$ on, and many singers and sellers of songs were persecuted by the inquisition. ${ }^{20}$ In the context of the reformation, song was a powerful (or dangerous) medium indeed, not only as a vehicle for spreading the ideas of reformers, but also as an encouragement to, and reinforcement for followers of the new religion. We should remind ourselves that singing is essentially a social activity, something done together in harmony, be it the singing of psalms in times of persecution, or, nowadays, 'Happy Birthday', the national anthem, or a song supporting a football club. Singing together gives a 'collective sense of identity and feeling of community'.21 This is something universal, and in turbulent times authorities tend to disapprove of it.

'Warum Lyrik?' If we narrow 'Lyrik' to 'song', my answer to the central question of this volume would be: because of its unique powers. Song can bring cohesion to a group. Equally importantly, however, as the authors of the sixteenthcentury prefaces stress, song has a profound influence through its exciting or even overwhelming emotional impact. As a medium, song can do this because of its particular combination of lyrics and music. In this combination, the

\footnotetext{
17 De Bruin (2002) esp. 34 (also available at: http://www.meertens.knaw.nl/respons/o5o6 .martine.pdf).

18 Asaert (2004) 247.

19 Grijp (2001) 168-173; Vanderhaeghen (1872-1881) part 1, cap. xIV, also available at http:// www.dbnl.org/tekst/vaeroo3vando1_o1/colofon.htm\%2o.

20 Decavele (1975) part I, 551; Ramakers (1997) 154-155.

21 Whiteley, Bennett, and Hawkins (2004) 4; Klusen (1989); Grijp (2000).
} 
music is of great importance. I will focus on its impact in the second part of this article, comparing medieval and modern accounts of the phenomenon.

As already mentioned, the sixteenth-century prefaces refer to important authorities on the subject that were well-known at the time: the Bible, the church father Athanasius and - even more importantly-Augustine, who discussed the beneficial and dangerous potential of music. In his Confessiones, Augustine describes how he was moved when he heard the hymns and canticles in church: 'Those voices flowed into my ears, and the truth was poured out in my heart, whence a feeling of piety surged up and my tears ran down. And these things were good for me, ${ }^{22}$ but he also has scruples about the pleasure he takes in hearing the psalms when they are sung by a skilled voice (Confessiones $\mathrm{x}, \mathrm{xxxIII)}$. Not only the Church fathers, but Greek and Roman philosophers wrote about the influence of music on human beings as well, with Boethius ranking as the most influential among them. His De institutione musica (ca. 500) was the most significant music treatise throughout the Middle Ages and well into the seventeenth century. ${ }^{23}$ In the first chapters of this work, Boethius discusses the connections between music and humans. According to him, knowledge of mathematics is necessary in order to understand aural perception: 'For the sense of hearing can apprehend sounds in such a way that it not only judges them and recognizes their differences, but it very often takes pleasure in them if they are in the form of sweet and well-ordered modes, whereas it finds displeasure if the sounds heard are unordered and incoherent. 24 This can be explained by an underlying principle: the unity of body and soul is determined by 'the same proportions that join together and unite the harmonious influences of music. Hence it happens that sweet melodies even delight infants, whereas a harsh and rough sound will interrupt their pleasure.'. ${ }^{25}$ Boethius discerns three categories of music: musica mundana, musica humana, and musica instrumentalis. Musica mundana is the force behind the harmony of the universe, responsible for all celestial motion, the structure of the elements and the seasons of the year. Musica humana is music as a unifying principle in human beings: a harmony uniting reason and body, the rational and irrational parts of the human soul and the disparate members

22 Confessiones IX, VI, in: McKinnon (1987), which gives a valuable survey of early Christian authors on music, from the New Testament to approximately $45 \mathrm{O}$ AD. Augustine also wrote a treatise of six books on music as a liberal art, De Musica, see Keller (1993) and Knight (1949).

23 For medieval views on music and emotion, see: Vellekoop (1994) and Vellekoop (1998).

24 Bower (1967) 32.

25 Bower (1967) 42. 
of the body. ${ }^{26}$ Musica instrumentalis is the only kind of music that is audible for humans, and is only an inferior reflection of the divine harmonies underlying the cosmos and the body. Thus 'harmony' is the key word in Boethean musical discourse: 'The power of the musica instrumentalis to influence man was inextricably linked to the presumed existence of the same harmonies and mathematico-musical proportions within the body, which in turn was tied in to the religio-musical cosmology.'27

Nowadays, we don't think in terms of harmonies of the spheres, but nevertheless the strong emotional power of music is still well known: we put on our favourite CD to calm down after a day of hard work; horror movies induce a feeling of terror by the soundtrack; we carefully choose appropriate music for the funeral of a beloved. Emotional response to music seems to be a timeless issue, regardless of the various scientific accounts we find for the phenomenon. However, recent insights from the field of musicology, specifically music cognition, might help to illuminate the past.

For example, in an experiment by John Sloboda, subjects were asked to specify particular pieces of music to which they could recall having experienced any physical manifestation of emotion, such as tears, lump in the throat, goose bumps, shivers down the spine or a racing heart. ${ }^{28} \mathrm{~A}$ significant proportion was able to locate their reaction within a musical theme, or even a smaller unit. Then the musical segments were classified according to the musical features they contained, and according to the emotional reactions they provoked. It was established that shivers were connected to a new or unexpected harmony in the music, while heart reactions were associated with repeated syncopations. The study demonstrates that expectation and the violation of expectation play a major role in promoting emotional reactions to music; these reactions even manifest themselves physically.

The properties of music as an acoustic, psychological and cognitive phenomenon are studied in music cognition, a rapidly growing field of inquiry. ${ }^{29}$ Some of the foci of scholarship are: a) musical origins and musical character (e.g. Why do people make music? Does music-making contribute to human

26 Bower (1967) 47-48; Boethius promises to return to this topic later, but unfortunately he never does, or this part did not come down to us: his treatise breaks off in the middle of book 5 .

27 Willis (2010) 16.

28 Sloboda (2005) 209-213. An elaboration of the importance of expectations is provided van David Huron who identified several categories of expectancy responses, preoutcome (imagination and tension) and postoutcome responses (prediction, reaction and appraisal), Huron (2006).

For a short introduction, see: Honing (2006) (also available on http://www.mcg.uva.nl/). 
survival in some way?), b) musical skill and musical intelligence (e.g. Why are some people more musical than others? What are the elements of musical ability?), c) musical pleasure and preference (e.g. How does music give pleasure? Why does the sound of fingernails scratching a blackboard sound so bad?), d) musical organization (e.g. Is music somehow similar to speech or language? Why are melody and rhythm so important in music?), e) music and memory (e.g. Why do some melodies get stuck in your head? How are musical memories stored in the brain?), f) music, brain and body (e.g. How is music, how are aspects of music (such as pitch or timbre) represented in the brain? How does illness or physiology affect our experience of music?) and g) music, environment and culture (e.g. Can we understand the music of another culture in the same way as people from that culture do? How do children become accultured to a particular music?). ${ }^{30}$ This overview of questions shows that music cognition is a truly interdisciplinary field to which specialists from different areas contribute. Researchers include those interested in evolutionary perspectives on music, who ask whether music might have developed as a part of human mating behaviour; psychologists interested in human cognition, who want to understand the connection between music and emotions against the background of studies on the role of emotion in memory, reasoning and problem solving; and neuroscientists who study brain function using techniques like neuroimaging and insights gained from studies of patients with brain damage. $^{31}$

For our purposes, however, the most important issue is the connection between music and emotion, because the writers of the sixteenth-century paratexts emphasized that songs can induce and enhance emotions. This link between music and emotions is the subject of a scholarly debate, with contributions from different points of view. ${ }^{32}$

To begin with, sound in general has a specific power to arouse feelings, because we feel the vibrations within our bodies, whereas visual stimuli always stay outside us: we see them but they remain detached from us. ${ }^{33}$ In addition, some researchers hold that music refers to emotion because of a certain resemblance between musical patterns and emotional states. ${ }^{34}$ Recently Patrik Juslin

30 These questions are taken from the site of the Music Cognition Group of the Ohio State University (http://www.musiccog. http ohio-state.edu), were a lot of interesting information about the field of music cognition can be found. Date of access 2-11-20og. Thompson (2009) offers an accessible introduction to the most important issues in music cognition.

32 In summarizing this debate, I follow Thomson (2009) chapter 6.

33 Thomson (2009) 125, referring to the philosopher John Dewey (1934).

34 Thomson (2009) 128-130. 
and Daniel Västfäll have drawn attention to the underlying mechanisms by which music can induce emotion. ${ }^{35}$ They distinguish six psychological mechanisms: the brain stem reflex (which occurs in response to a sudden change in environmental noise, such as loud or sudden sounds), emotional contagion (an emotion expressed in the music gives rise to the same emotion in the listener, a process that may occur through the operation of so-called mirror neurons), musical expectancy (which occurs when a specific feature of music delays, violates or confirms the listener's expectation; the aforementioned experiment by Slobada is an example of this), evaluative conditioning (which refers to a process of conditioning, when a certain piece of music has been repeatedly associated with a positive or negative occasion), visual imagery (listening to music may give rise to visual images that can trigger emotions), episodic memory (also called the 'Darling, they are playing our tune' phenomenon: when a song is attached to a particular important event in the life of the listener). With the last three mechanisms, the emotion comes from the music only in an indirect way: it is remembering the episode, the association with the occasion or the vision that triggers the emotion. In short, within psychology, questions concerning music and emotion are hotly debated, but for the time being the different approaches tend to make it impossible to compare outcomes.

The issue of music and emotion is fundamental for neuroscientists as well as cognitive psychologists. Neuroscientists generally accept that thoughts, emotions and memories arise from the firing of neurons, from electrochemical activity in the brain. So studying the firing of neurons is another way of trying to understand emotions. Therefore neuroscientists endeavour to pinpoint what happens in the human brain during the act of listening to music. In order to do this, they use several brain imagining techniques: EEG's to find out when and how often neurons are firing; fMRI (functional magnetic resonance imaging) to see increased neural activity in specific locations in the brain. ${ }^{36}$

In this way, neuroscientists can observe what parts of the brain are activated when individuals are listening to music. The crucial part seems to be the cerebellum. Evolutionarily the cerebellum is one of the oldest parts of the brain, and is therefore sometimes called the reptilian brain. It is involved in timing

35 Juslin and Västfäll (2008) (including 25 open peer commentaries and the authors' response).

36 An fMRI machine can trace changes of magnetic properties in the human body at any given moment. Because blood is slightly magnetic, and because blood will flow to those regions of the brain that are involved in a particular cognitive task to supply them with oxygen, fMRI-images will show the increased blood flow and thus detect the particular part of the brain involved in that task, see Levitin (2006) 125-129. 
and coordinating body movements, which is, of course, relevant for music (and is activated when listening to music, but not when listening to noise). Interestingly enough, the cerebellum is also involved in emotion: it is massively connected to emotional centres of the brain. One of these is the amygdala, which is involved in processing emotions as well as in memory-this explains why music has such strong power to bring back memories. Another important centre is the nucleus accumbens (part of the ventral striatum): the centre of the brain's reward system that releases the neurotransmitter dopamine, the feelgood hormone that plays an important role in pleasure and addiction (whether through using drugs, eating chocolate, having sex or from listening to beautiful music). So the pleasure of listening to music can be explained by the resulting increased dopamine levels in the brain.

The cerebellum also sends neurons to the frontal lobe: the part of the brain involved in planning and impulse control, and in perceiving structure, for example in language or music. Remarkable about all this is the integration between the different systems in the brain. The logical prediction systems and the emotional reward systems all work together when we listen to music. For instance, when we compare music to language, music 'invokes some of the same neural regions as language does, but far more than language, music taps into primitive brain structures involved in motivation, reward, and emotion.'37 Such results of neuroscientific research help to explain how and why music has such a strong influence on emotions and memory.

Much of the research discussed so far concerns instrumental music only, not song. There is of course a reason for this: the lyrics of the song add an extra variable in the experimental situation. However, the combination of words and music does matter to the focus of this volume. Philosopher Jenefer Robinson has long been working on the role of emotion in literature, art and music, with a particular interest in the Lieder of the Romantic Period. ${ }^{38}$ She discusses the different relationships between emotion and music: how music can represent emotions, how music can express emotions and how music can arouse emotions. First, Robinson maintains that music alone cannot represent emotion, because music is not able to depict particular things. A painting can be a picture of something particular: Rouen Cathedral at the end of the day, the bar at the Folie-Bergère, a starry night in June. But music cannot do that: even a descriptive piece like La mer by Claude Debussy 'could easily be a description of different kinds of weather or different people's temperaments rather than

The discussion of the brain regions involved in emotions while listening to music is taken from Levitin (2006) 169-191, here p. 191. 
the different moods of the sea. ${ }^{39}$ Second, music does arouse feelings. Agreeing with neuroscientists such as Levitin, Robinson argues that much of the arousal effect of music occurs below the level of consciousness: the rhythm affects human motor systems, disruption of the musical harmony causes unease, and the movement of the melody imparts itself to the listener. Then, in the case of song, the lyrics help the listener to determine what is being expressed: the music might reinforce what the text indicates. ${ }^{40}$ So according to Robinson, in song the text adds strength to the subconscious effects of the music, and these different mechanisms reinforce each other. This explains why the effect of song can be so overwhelming: song arouses various emotions on a conscious and a subconscious level at the same time.

This paper began with analysing sixteenth-century attitudes towards song: song was regarded as influential as well as dangerous, because it was thought to have a strong physical and emotional impact. In classical and medieval thought, the issue had to do with the concept of harmony, and thus with the relation between human beings and the cosmos. Modern research on music and emotion, in fields such as musical cognition and neuroscience, discusses the power of songs in terms of expectations and the firing of neurons. Clearly both explanations are grounded in different world views: central to the older line of reasoning is the parallel of man and universe, while the modern account is rooted in the conviction that emotions result from electrochemical activity in the brain. However, in the end, there may be little difference between the two approaches: each is a serious attempt to describe the fascinating power of song, a literary-musical form particularly suited as a medium to address the emotional as well as the rational capacities of singers and listeners, and therefore an excellent medium to use in times of controversy.

\section{Bibliography}

Asaert, G. 2004. 1585. De val van Antwerpen en de uittocht van Vlamingen en Brabanders. Tielt.

Bax, D. 1944. Het wereldlijke lied van de xvie eeuw, with a musicological commentary by R. Lenaerts. In De letterkunde van de Renaissance tot Roemer Visscher en zijn dochters, ed. G.S. Overdiep. Antwerpen (Geschiedenis van de letterkunde der Nederlanden 3): 242-275.

39 Robinson (2007) 396.

40 Robinson (2007) 415-417. 
Van Biezen, J., and Veldhuyzen, M. (ed.) 1984. Willem van Zuylen van Nyevelt (?), Souterliedekens 1540. Buren (Facsimile of Dutch songbooks 2).

Bonda, J.W. 2001. Meerstemmige liederen op Nederlandse teksten: Tielman Susato roept op in de eigen taal te componeren. In Een muziekgeschiedenis der Nederlanden, ed. L.P. Grijp. Amsterdam 152-159.

Bower, C.M. 1967. Boethius' The Principles of Music. An Introduction, Translation, and Commentary. Ann Harbor, Mi [dissertation].

De Bruin, M. 2002. Het muzikale behang van de zestiende eeuw. Het Nederlandse lied tot 1600 in kaart gebracht. Respons 5: 28-34.

Decavele, J. 1975. De dageraad van de reformatie in Vlaanderen 1520-1565. 2 vol. Brussel.

Forney, K.K. 1982-1984. New Documents on the Life of Tielman Susato, Sixteenthcentury Music Printer and Musician. Revue belge de musicologie / Belgisch tijdschrift voor muziekwetenschap 36-38: 18-52.

De Gier, J. 1987. Van de Souterliedekens tot Marnix. Stromingen en genres binnen de letterkunde der hervorming in de zestiende eeuw. Kampen (Reformatie reeks 21).

Grijp, L.P. 200o. Zangcultuur. In Volkscultuur. Inleiding in de Nederlandse etnologie, ed. T. Dekker, H. Roodenburg and G. Rooijakkers. Nijmegen: 337-380.

Grijp, L.P. 2001. De honger naar psalmen en schriftuurlijke liederen tijdens de Reformatie. Groepen mensen lopen luid psalmen zingend door de stad. In Een muziekgeschiedenis der Nederlanden, ed. L.P. Grijp. Amsterdam: 168-173.

Honing, H. 20o6. On the Growing Role of Observation, Formalization and Experimental Method in Musicology. Experimental Musicology Review 1: 2-6.

Huron, D. 2006. Sweet anticipation. Music and the Psychology of Expectation. Cambridge, Mass.

Juslin, P.N., and Västfjäll, D. 2008. Emotional responses to Music. The Need to Consider underlying Mechanisms. Behavorial and Brain Sciences 31: 559-621.

Keller, A. 1993. Aurelius Augustinus und die Musik. Würzburg.

Knight, W.F. 1949. St. Augustine's De musica. A synopsis. London.

Klusen, E. 1989. Singen, Materialien zu einer Theorie. Regensburg.

Knuttel, J.A.N. 19o6. Het geestelijk lied in de Nederlanden voor de kerkhervorming. Rotterdam.

Lenselink, S.J. 1983. De Nederlandse psalmberijmingen van de Souterliedekens tot Datheen. Met hun voorgangers in Duitsland en Frankrijk. 2nd edition. Dordrecht.

Levitin, D. 2006. This is your Brain on Music. Understanding a Human Obsession. London.

Maes, L.Th. 1947. Vijf eeuwen stedelijk strafrecht. Bijdrage tot de rechts- en cultuurgeschiedenis der Nederlanden. Antwerpen.

McKinnon, J. 1987. Music in early Christian literature. Cambridge.

McTaggart, T. 1997. Music for a Flemish Middle Class. Music Printing in Antwerp and Europe in the 16th Century (Yearbook of the Alamire Foundation 1997): 307-332. 
Pleij, H. 2007. Het gevleugelde woord. Amsterdam (Geschiedenis van de Nederlandse literatuur 1400-1560).

Vanderhaeghen, F. (ed.) 1872-1881. Marcus van Vaernewyck. Van die beroerlicke tijden in die Nederlanden en voornamelick in Ghendt 1566-1568. 5 vol. Gent.

Van der Poel, D.E. 2005. Het Antwerps Liedboek compleet. Nederlandse Letterkunde 10: $80-85$.

Van der Poel, D.E., Geirnaert, D., Joldersma, H., and Oosterman, J.B. (ed.) 2004. Het Antwerps Liedboek. Reconstructie van de melodieën door Louis Peter Grijp. 2 vol. Tielt.

Polk, K. 2005. Tielman Susato and the Music of his Time. Print Culture, Compositional Technique and Instrumental Music in the Renaissance. New York.

Ramakers, B.A.M. 1997. Epiloogliederen, factieliederen en de Brabantse connectie. In Veelderhande Liedekens. Studies over het Nederlandse lied tot 1600. Symposium Antwerpen 28 februari 1995, ed. F. Willaert. Leuven (Antwerpse Studies over Nederlandse Literatuurgeschiedenis 2): 149-159.

Riemsdijk, J.C.M. van (ed.) 1888. De twee eerste musyckboekskens van Tielman Susato. Bijdrage tot

het Nederlandsch Volkslied in de 16de eeuw. Tijdschrift der Vereeniging voor NoordNederlandse Muziekgeschiedenis 3: 61-110.

Robinson, J. 2005. Deeper than Reason. Emotion and its Role in Literature, Music and Art. Oxford.

Robinson, J. 2007. Music and Emotions. Journal of Literary Theory 1: 395-419.

Scheurleer, D.F. 1889. Een devoot ende profitelyck boecxken in houdende veel gheestelijcke Liedekens ende Leysenen, diemen tot deser tijt toe heeft connen ghevinden in prente oft in ghescrifte. Geestelijk liedboek met melodieën van 1539. 's-Gravenhage.

Scheurleer, D.F. 1898. Jan Fruytiers, Ecclesiasticus, oft de wijse sproken Jesu des soons Syrach. Nu eerstmael deurdeelt ende ghestelt in liedekens, op bequame en ghemeyne voisen naer uutwijsen der musijck-noten daer by ghevoecht. Amsterdam.

Scheurleer, D.F. 1977. De Souterliedekens. Bijdrage tot de geschiedenis der oudste Nederlandsche psalmberijming. Utrecht, reprint of the Leiden 1898 edition.

Siertsema, G. 1993. Psalm translations in the Low Countries 1539-16oo and their European context. In From revolt to riches: culture and history of the Low Countries 15001700. International and interdisciplinary perspectives, ed. T. Hermans and R. Salverda. London (Crossways 2): 49-64.

Sloboda, J. 2005. Exploring the musical mind. Cognition, emotion, ability, function. Oxford.

Thompson, W.F. 2009. Music, Thought, and Feeling. Understanding the Psychology of Music. Oxford.

Vellekoop, C. 1994. Musica movet affectus. Utrecht.

Vellekoop, K. 1997. Een liedboekje in het Devoot ende profitelijck boecxken. De werkwijze van een verzamelaar. In Veelderhande Liedekens. Studies over het Nederlandse 
lied tot 1600. Symposium Antwerpen 28 februari 1995, ed. F. Willaert. Leuven (Antwerpse Studies over Nederlandse Literatuurgeschiedenis 2): 103-117.

Vellekoop, C. 1998. De expressie van emoties in muziek en drama. In Emoties in de Middeleeuwen, ed. R.E.V. Stuip and C. Vellekoop. Hilversum (Utrechtse bijdragen tot de mediëvistiek 15): 79-95.

Whiteley, S., Bennett A., and Hawkins S. (ed.) 2004. Music, Space and Place. Popular Music and Cultural Identity. Aldershot.

Willis, J. 2010. Church Music and Protestantism in Post-Reformation England. Discourses, Sites and Identities. Franhem. 